\title{
POLITIK KEKUASAAN GIRISAWARDHANA DALAM NOVEL SABDO PALON PUDARNYA SURYA MAJAPAHIT KARYA DAMAR SHASHANGKA
}

\author{
Suria Dewi Fatma ${ }^{1)}$ \\ ${ }^{1}$ Polda Sumatera Barat \\ email: suriadewifatma83@yahoo.com \\ https://doi.org/10.25077/majis.1.1.27-35.2019
}

\begin{abstract}
Kajian ini membicarakan tentang politik kekuasaan di Majapahit yang terjadi pada tahun 1373-1380 Saka atau sekitar tahun 1451-1457 Masehi. Dalam hal ini, politik kekuasaan merujuk pada penyalahgunaan wewenang dan konspirasi politik yang dilakukan oleh Girisawardhana (raja Majapahit yang baru) untuk meperluas wilayah kekuasaannya. Politik kekuasaan dalam Novel Sabdo Palon Pudarnya Surya Majapahit Karya Damar Shashangka juga dapat ditemukan melalui memanasnya situasi politik di Majapahit pasca Girisawardhana membuat dan menerbitkan aturan baru yang menimbulkan reaksi/penentangan dari berbagai pihak, salah satunya adalah Bhre Kertabhumi (Raja Kerajaan Keling). Pada penelitian ini, peneliti menggunakan metode kualitatif deskriptif untuk menafsirkan politik kekuasaan Girisawardhana dalam Novel Sabdo Palon Pudarnya Surya Majapahit. Adapun teori yang digunakan mengacu pada pandangan Max Weber tentang kekuasaan. Kesimpulan dari penelitian ini mengindikasikan bahwa politik kekuasaan mempengaruhi suatu masa atau peradaban, karena kekuasaan (penguasa) akan berupaya menguasai dan menakhlukkan kelompok atau golongan yang bertentangan dengan kebijakan dan ideologi sang penguasa. Namun, dalam politik kekuasaan terdapat sebuah wacana ataupun konspirasi dengan tujuan tertentu untuk mengusai suatu kaum dan juga bisa membungkam kelompok atau golongan tertentu yang dianggap separatis/kaum pemberontak. Hal ini mengindikasikan bahwa semakin besar pengaruh politik kekuasaan, maka akan semakin besar pula keinginan untuk menundukkan dan mempengaruhi orang lain.
\end{abstract}

Keywords: Novel, Politik Kekuasaan, Girisawardhana, Bhre Kertabhumi, Majapahit.

\section{PENDAHULUAN}

Runtuhnya kerajaan Majapahit tidak terlepas dari banyaknya peristiwa besar yang menaungi kerajaan besar tersebut terutama dalam hal politik kekuasaan yang secara terus menerus menimbulkan polemik sebagai akibat dari munculnya perang saudara dan perebutan kekuasaan. Tidak dapat dipungkiri bahwa politik kekuasaan terus menjadi problema berkepanjangan dan tak berkesudahan hingga saat ini. Penyalahgunaan kekuasaan di dunia politik, kerap menimbulkan pandangan negatif dari masyarakat bahwa tujuan utama dari politik hanyalah untuk mendapatkan kekuasaan.

Gabriel A. Almond mendefinisikan politik sebagai kegiatan yang berbuhungan dengan kendali pembuatan keputusan publik dalam masyarakat tertentu di wilayah tertentu, dimana kendali tersebut disokong melalui instrumen yang bersifat otoritatif dan koersif dalam hal ini, pembuatan keputusan publik akan berkaitan dengan siapa yang berwenang, bagaimana cara menggunakan kewenangan dan apa tujuan dari keputusan yang disepakati (2008:3). 


\section{Jurnal Ilmu Sastra}

Sedangkan kekuasaan adalah kemampuan untuk mempengaruhi tingkah laku dan pikiran orang lain, agar sesuai dengan keinginan dari orang yang memiliki kekuasaan itu sendiri (Miriam Budiardjo, 2003). Kekuasaan juga dapat diartikan sebagai kemampuan untuk mempengaruhi pihak lain agar mau mengikuti kehendak dari orang yang memiliki kekuasaan.

Sebelum menelusuri lebih jauh tentang politik kekuasaan Girisawardhana (raja baru Majapahit), ada baiknya kita mengetahui terlebih dahulu apa itu politik kekuasaan. Politik kekuasaan adalah kemampuan suatu individu atau suatu kelompok untuk memanfaatkan sumber-sumber kekuatan, yang dapat menunjang kekuasaan dalam rangka mencapai tujuan tertentu. Sumbersumber tersebut bisa didapat melalui elit politik, tokoh masyarakat ataupun militer (2009:31).

Dalam $\mathrm{k}$
rangkaian komp Pemimpin mempengaruhi penguasa dalam menjalankan tampuk kekuasaannya. Tiga komponen tersebut meliputi pemimpin (pemilik atau pengendali kekuasaan), pengikut dan situasi. Yang dapat dilihat pada gambar berikut ini.

Dari gambar tersebut dapat diberikan penjelasan sebagai berikut. Pemimpin sebagai pemilik kekuasaan, bisa mempengaruhi pengikutnya. Bahkan juga bisa menciptakan pengikut, menggiring pengikut, menjadi provokator pengikut, sehingga kepengikutan si pengikut akan membabi buta dan tidak rasional lagi. Begitu juga sebaliknya, pengikut juga bisa mempengaruhi pemimpin, bisa memberikan bisikan / masukan kepada pemimpin, bisa menyuruh untuk mempertahankan kekuasaan dan juga bisa menjatuhkan kekuasaannya. Seorang pemimpin bisa menciptakan suatu situasi dan juga bisa merekayasa situasi. Namun juga perlu diingat bahwa situasi yang ditimbulkan bisa menguntungkan dan juga bisa menjadi bumerang bagi pemimpin itu sendiri salah satunya dapat mengakhiri tampuk kekuasaan dari pemimpin itu sendiri. Dalam hal ini, dibutuhkan figur seorang pemimpin yang benar-benar cerdas, matang dan cermat dalam hal memperhitungkan situasi yang sedang diciptakannya.

Namun Kenyataannya, penyalahgunaan kekuasaan dalam dunia politik tidak bisa dihindari. Persoalan yang terjadi di ranah politik kerap menimbulkan persoalan baru dan menimbulkan reaksi dari berbagai pihak baik pihak yang pro maupun pihak yang kontra. Kebanyakan politik digunakan sebagai sarana untuk mendapatkan kekuasaan. Padahal, penggunaan kekuasaan dalam politik bertujuan untuk mengatur kepentingan semua orang yang ada dalam organisasi, bukan untuk kepentingan pribadi ataupun kelompok tertentu.

Penyalahgunaan politik kekuasaan inilah yang terjadi di Majapahit, tepatnya ketika Bathara Ring Majapahit mangkat dan tampuk kekuasaan dipegang oleh Girisawardhana. Pada masa itu banyak aturan yang dilanggar mulai dari pencaplokan tapal batas dilwilayah kerajaan Keling yang dikuasai oleh Bhre Kertabhumi, upaya pembunuhan terhadap Raden Jaka Sujanma (putra Bhre Kertabhumi) dan upaya kudeta yang dilakukan oleh prajurit laut Majapahit dengan ditemukannya bubuk mesiu di Sumengka tepatnya ditengah aliran Canggu untuk menimbulkan suasana gaduh disekitar Majapahit.

Pada penelitian ini, pembahasan hanya terbatas pada politik kekuasaan Girisawardhana yang terdapat dalam Novel Sabdo Palon Pudarnya Surya Majapahit karya Damar Shashangka.

\section{METODE PENELITIAN}

Analisis ini menggunakan metode kualitatif deskriptif dalam menafsirkan 


\section{Jurnal Ilmu Sastra}

politik kekuasaan Girisawardhana dari karya sastra, yakni Novel Sabdo Palon Pudarnya Surya Majapahit karya Damar Shashangka. Penelitian kualitatif adalah penelitian yang menghasilkan data deskriptif berupa kata-kata tertulis atau lisan dari orang-orang dan perilaku yang dapat diamati. Penelitian kualitatif adalah mendeskripsikan makna data atau fenomena yang dapat ditangkap oleh peneliti dengan menunjukkan bukti. Fitur-fitur penting dari kualitatif penelitian dalam studi literatur, antara lain: Peneliti adalah instrumen kunci yang akan membaca dengan seksama karya sastra; penelitian dilakukan secara deskriptif, artinya dipecah dalam bentuk kata atau gambar jika diperlukan, bukan dalam bentuk angka; memprioritaskan proses dibandingkan dengan hasil, karena karya sastra adalah fenomena yang mengundang banyak interpretasi; analisis induktif; dan artinya adalah fundamental (Endraswara, 2011).

Dalam studi politik kekuasaan Girisawardhana khususnya dalam Novel Sabdo Palon Pudarnya Surya Majapahit, peneliti menggunakan metode deskriptif kualitatif untuk menggambarkan situasi aktual, yaitu menafsirkan peristiwa yang terjadi di Majapahit pasca mangkatnya Bathara Ring Majapahit dimana tahta Majapahit jatuh ketangan Girisawardhana. Adapun peristiwa yang terjadi meliputi : pencaplokan tapal batas dilwilayah kerajaan Keling yang dikuasai Bhre Kertabhumi, upaya pembunuhan terhadap Raden Jaka Sujanma (putra Bhre Kertabhumi) dan upaya kudeta yang dilakukan oleh prajurit laut Majapahit dengan ditemukannya bubuk mesiu di Sumengka tepatnya ditengah aliran Canggu.

Dengan metode ini, data yang telah dikumpulkan, diidentifikasi, dianalisis, dijelaskan, kemudian ditafsirkan sesuai dengan tujuan yang dinyatakan.

\section{HASIL DAN PEMBAHASAN}

\section{Politik Kekuasaan dalam Sastra}

Hubungan sastra dan politik seumpama dua sisi mata uang yang saling terhubung dan tidak dapat dipisahkan antara yang satu dengan yang lainnya. Sejarah telah mengungkap bahwa para sastrawan pada masa lampau juga di manfaatkan oleh pihak kerajaan untuk kepentingan kekuasaannya. Dalam hal ini, seorang sastrawan dan karya sastranya digunakan sebagai alat untuk melegitimasi kekuasaan sang raja. Sebagai contoh Empu Prapanca yang merupakan seorang pujangga pada masa Majapahit, dimana ia direkrut dan dipekerjakan di lingkungan istana oleh Raja Hayam Wuruk. Pada masa itu, Empu Prapanca banyak menulis cerita atau syair yang berhubungan dengan kebaikan, ketangguhan dan kehebatan dari sang raja. Ini menunjukan bahwa seorang sastrawan dan karyanya dikondisikan sebagai alat politik untuk mengukuhkan dan meyakinkan masyarakat bahwa citra sang raja benar-benar tangguh dan luar biasa sesuai dengan apa yang ia tulis dan wartakan dalam setiap untaian syair dan karyanya.

Pada masa modern ditemukan karya sastra terbitan Balai Pustaka. Balai Pustaka digunakan sebagai bentuk perlawanan kolonialisme Belanda kepada para sastrawan Indonesia khususnya sastrawan aliran garis keras yang sering melakukan perlawanan dan mengkritik kebijakan pemerintah Belanda pada masa itu. Tak ayal, banyak karya dari tokoh-tokoh Balai Pustaka dilakukan sensor secara habishabisan sebelum diterbitkan kepada khalayak umum. Sebagai contoh Novel Salah Asuh karya Abdul Muis (1928), Novel Siti Nurbaya karya Marah Rusli (1922), Novel Azab dan Sengsara karya Merari Siregar (1920), Novel Muda 


\section{Jurnal Ilmu Sastra}

Dalam Taruna karya Moehammad Kasim (1922), Novel Asmara Jaya karya Adi Negoro (1928), Novel Sengsara Menbawa Nikmat karya Sutan Sati (1928) dan Novel Hulubalang Raja karya Nur Sutan Iskandar (1934).

Sastra dan politik akan selalu bertemu, apalagi pada masa orde baru yang menganut paham represif. Kala itu, banyak sastrawan yang mengkritik tajam pemerintah akan berakhir dalam tahanan (sel penjara), sebagai contoh WS. Rendra yang dilarang menampilkan teaternya dimasa Orde Baru, diperparah dengan hilangnya nyawa dan jasad dari sang pengkritisi yang tidak diketahui rimbanya hingga saat ini. Adapun karya sastra yang hadir pada masa orde baru yakni Taufik Ismail dalam karyanya Malu (Aku) Jadi Orang Indonesia, Tirani dan Benteng, Buku Tamu Musim Perjuangan, Sajak Ladang Jagung, Kenalkan, Hewan Saya dan Puisipuisi Langit. Sapardi Djoko Damono dalam karyanya Dukamu Abadi (1969) dan Mata Pisau (1974). Goenawan Muhamad dalam karya Parikesit (1969), Interlude (1971), Potret Seorang Penyair Muda Sebagai Si Malin Kundang (1972), Seks, Sastra dan Kita (1980). Chairul Harun dalam karyanya Warisan (1979), Kunto Wijoyo dan Khotbah di Atas Bukit (1976).

Untuk lebih identiknya lagi politik kekusaan sangat mudah dijumpai dalam novel-novel yang bertemakan sejarah masa lampau seperti novel Wangsit Siliwangi Harimau di Tengah Bara karya E. Rokajat Asura, novel Sabdo Palon Pudarnya Surya Majapahit karya Damar Shashangka dan novel The Road To The Empire karya Sinta Yudisia.

Walaupun antara sastra dan politik memiliki ikatan yang sangat kompleks dengan penguasa, namun kadang kala ia dapat berjalan bergandengan tangan antara yang satu dengan yang lainnya dan kadang kala juga saling berseberangan. Maka wajar-wajar saja jika sastra akan selalu menimbulkan pro dan kontra dalam dunia politik.

Adapun para pakar yang berbicara masalah masalah kekuasaan, ideologi, dan politik dalam dunia kesusastraan misalnya Goenawan Muhamad 1983) dan Sapardi Djoko Damono (1978, 1994 dan 1999), yang secara umum mencoba mengaitkan hubungan antara dunia pengarang, pembaca, karya sastra dan penguasa (Damono, 1979:249-250).

\section{Teori Kekuasaan dalam Kacamata Max Weber}

Max Weber mendefinisikan kekuasaan sebagai kemungkinan bagi seseorang untuk memaksakan orang lain agar berperilaku sesuai dengan kehendaknya (2001:190). Max Weber mengemukakan beberapa bentuk wewenang manusia yang hubungan dengan kekuasaan diantaranya wewenang (authority) yaitu kemampuan untuk mencapai tujuan-tujuan tertentu yang diterima secara formal oleh anggota-anggota masyarakat (Hotman Siahaan, 1986:201). Jenis authority yang disebutnya dengan rational legal authority sebagai bentuk hirarki wewenang yang berkembang di dalam kehidupan masyarakat modern. Wewenang tersebut kemudian dibangun atas dasar legitimasi (keabsahan) menurut pihak yang berkuasa (George Ritzer \& Douglad J. Goodman, 2007:37).

Politik kekuasaan diperlukan untuk mendukung dan menjamin jalannya sebuah keputusan politik dalam kehidupan masyarakat. Keterkaitan logis antara politik dan kekuasaan menjadikan setiap pembahasan tentang politik yang selalu melibatkan kekuasaan didalamnya. Sekularisasi politik secara implisif bertujuan untuk mendesakralisasi kekuasaan untuk tidak dilegimitasi sebagai sesuatu yang bersifat sakral atau suci. Pada 


\section{Jurnal Ilmu Sastra}

prinsipnya, kekuasaan sebagai aktivitas politik harus dipahami sebagai kegiatan manusiawi yang diraih, dipertahankan dan sekaligus direproduksi secara terus menerus (2004:169).

Kekuasaan (power) digambarkan dengan berbagai cara yang diartikan sebagai kemungkinan mempengaruhi tingkah laku orang lain agar sesuai dengan tujuan-tujuan dari sang aktor (Hoogerwerf, 1985:144). Hal ini mengindikasikan bahwa politik tanpa adanya kekuasaan akan terasa tidak masuk akal dan relatif mustahil. Dalam artian selama manusia menganut pendirian politik yang berbeda-beda, jika hendak mewujudkan dan melaksanakan sesuai kebijakan pemerintah, maka diperlukan suatu usaha untuk mempengaruhi tingkah laku orang lain dengan jalan menggunakan pertimbangan yang tepat (Hoogerwerf, 1985: 145-146). Kekuasaan senantiasa ada di dalam masyarakat. Walaupun demikian, akan tetap selalu ada kekuasaan yang tidak dapat dibagi rata kepada semua anggota masyarakat (Soekanto, 1994:265).

\section{Politik Kekuasaan Girisawar-Dhana Dalam Novel Sabdo Palon Pudarnya Surya Majapahit}

Politik kekuasaan di Majapahit berawal dari mangkatnya Bathara Ring Majapahit (Rajasawardhana) dan tahta jatuh ke tangan penerus selanjutnya yakni Girisawardhana pada 1378 Saka/1456 Masehi. Pada masa kepemimpinannya, Girisawarhana banyak melanggar aturan terutama dalam hal kebijakan yang berkaitan dengan hajat hidup orang banyak.

Diawal

Girisawardhana berkinginan untuk memperluas wilayah kekuasaan Majapahit dengan mengabaikan tapal batas milik kerajaan lain. Dengan sikap arogansi karena telah memiliki kekuasaan, Girisawardhana mengutus prajurit Wengker untuk memasang panji-panji kerajaan disekitar ditapal batas kerajaan Keling. Sedangkan Girisawardhana sendiri sangat mengetahui dan memahami betul bahwa peletakan panji-panji tersebut akan menimbulkan riak dan reaksi dari Bhre Kertabhumi yang tak lain adalah sang penguasa kerajaan Keling.

Hal ini menunjukkan bahwa siapapun yang berkuasa akan berupaya mempengaruhi orang lain agar takhluk dan mengikuti aturan dari sang penguasa pada masa itu. Namun bagaimanapun hal yang demikian tidak dapat dibenarkan, karena kerajaan Keling bukanlah wilayah takhlukkan Majapahit, namun Keling merupakan suatu kerajaan yang otonom dan memiliki otoritas tersendiri yang tidak dapat dicampuradukkan dengan kekuasaan Majapahit, walaupun pada dasarnya diantara Bhre Kertabhumi dan Girisawardhana masih dalam satu trah/garis keturunan dari raja-raja sebelumnya.

Peletakan panji-panji ditapal batas kerajaan Keling selain bertujuan untuk memperluas wilayah kekuasaan Majapahit, namun juga terselubung suatu niat buruk untuk mempermalukan dan merusak harga diri Bhre Kertabhumi yang notabenya adalah raja Kerajaan Keling. Tidak dapat dipungkiri bahwa pengaruh Bhre Kertabhumi sangat kuat kala itu, saking kuatnya mampu memudarkan pamor dan citra dari seorang Girisawardhana.

Melalui peletakan panji ditapal batas kerajaan Keling, Girisawardhana ingin membuktikan bahwa dirinya mampu menakhlukkan Bhre Kertabhumi. Namun Girisawadhana tidak menyadari bahwa tindakan gegabah yang dilakukannya menjadi awal munculnya gesekan dan pertikaian diantara dua kubu yang notabenya masih satu garis keturunan.

Pada kala itu, pihak kerajaan Keling melakukan perlawanan karena tidak ingin wilayahnya dicaplok begitu saja oleh pihak Girisawardhana melalui perantara prajurit 


\section{Jurnal Ilmu Sastra}

Wengker. Untuk mengantisipasi hal-hal yang tidak diinginkan, maka pihak kerajaan Keling berupaya melakukan perundingan dengan Senopati Wengker, namun perundingan tersebut ditolak.

Hal ini membuktikan bahwa tidak adanya iktikad baik dari pihak penguasa khususnya prajurit Wengker (pihak Girisawardhana) untuk menarik mundur pasukannya dan mencabut panji-panji tersebut dari wilayah kerajaan Keling. Reaksi yang terjadi justru sebaliknya, Senopati Wengker memperlakukan Senopati Arya Bangah dan prajuritnya secara tidak manusiawi sehingga menimbulkan gejolak dan perlawanan tepatnya ditapal batas kerajaan Keling.

Merasa tidak senang dengan tindakan para prajurit Wengker yang sewenangwenang diwilayah kekuasaannya, kemudian Bhre Kertabhumi mengutus Senopati Arya Bangah dan para prajurit untuk mencabut dan membersihkan semua panji-panji kerajaan lain yang berkibar di wilayah Kerajaan Keling.

"Perbatasan ini milik Daha dan Keling! kami lihat panji-panji Wengker disini. Arya Bangah menghentikan ucapannya sejenak.

Beberapa saat kemudian, dia melanjutkan, Penguasa Keling, Pukulun Bhre Kertabhumi bertitah kepada kami untuk membersihkan panji-panji kerajaan lain yang berkibar diwilayah Keling, Tidak patut panji-panji itu berada disini! (Shashangka, 2016:351).

Pada waktu itu, permintaan Senopati Arya Bangah tidak diindahkan oleh Senopati Wengker dan justru mendapatkan perlawanan yang menyebabkan terjadinya bentrok diantara kedua kubu yang saling berseberangan. Kala itu kemenangan berhasil diraih oleh Kerajaan Keling yang diketuai oleh Arya Bangah.

"Menyerah kalian selamat!
melawan kalian tumpas semua!
Prajurit Wengker riuh. Wakil
Senopati Wengker turun dari kuda,
bersimpuh di atas tanah,
meletakkan senjata
menghaturkan sembah. Arya Bangah mengangguk-angguk, kemudian memberikan perintah: Tangkap Wakil Senopati Wengker! Empat prajurit Keling turun dari kuda, bergerak mendekati Wakil Senopati yang masih bersimpuh. Tubuhnya diikat dengan tali yang sudah disiapkan, dia hanya bisa pasrah dengan wajah pucat" (Shashangka, 2016:363)".

Kabar terjadinya bentrokan di DahaKeling dengan cepat tersebar hingga sampai ke Kotaraja Majapahit. Kemenangan mutlak Keling atas Wengker menjadi bukti nyata bahwa mereka tidak gentar terhadap hadangan dan serangan dari pasukan Wengker yang penguasanya adalah calon raja Majapahit. Di hari penobatan Girisawardhana sebagai raja, Bhre Kertabhumi membuat kehebohan tepatnya di depan semua kesatria Majapahit dengan meminta keadilan kepada Bathara Ring Majapahit yang baru atas peristiwa pemasangan panji-panji Wengker di wilayah kekuasaan Keling. Namun lagi-lagi Girisawardhana ingin lepas tangan atas peristiwa tersebut, sehingga Bhre Kertabhumi memutuskan untuk menghukum Wakil Senopati Wengker dan dibawa ke Kerajaan Keling.

Pada kala itu, Wakil Senopati Wengker tidak ditahan dan diberikan jabatan baru karena kemampuan dan sikap kesatria yang dimilikinya. Ketulusan Bhre Kertabhumi kemudian membuat Wakil Senopati Wengker bersumpah setia bahwa 


\section{Jurnal Ilmu Sastra}

ia akan mengabdikan seluruh hidupnya kepada Bhre Kertabhumi. Berita pengangkatan Wakil Senopati Wengker terdengar hingga sampai ke Kotajara dan Girisawardhana perlahan mulai tidak menemukan kedamaiannya, karena para bangsawan sudah mulai condong beralih perhatiannya kepada Bhre Kertabhumi dan dukungan yang diberikan kepadanyapun semakin menguat disegala lini sehingga menimbulkan ancaman bagi kekuasaan yang sedang dipegang oleh Girisawardhana (Shashangka, 2016:364-365).

Dengan semakin menguatnya dukungan terhadap Bhre Kertabhumi, secara tidak langsung menimbulkan gejolak dari orang-orang yang kurang senang akan prestasi Bhre Kertabhumi dalam memerintah Kerajaan Keling, salah satu tindakan yang dilakukan adalah upaya pembunuhan terhadap Raden Jaka Sujanma yang tidak lain adalah putera dari Bhre Kertabhumi.

"Kenapa kamu sampai disini, Janma? Nuwun duka rama. Saya dibawa Paman Panglet dan Paman Kupeng kemari dan ketangkap kethek lamuri. Bukankah seharusnya kamu ke Blambanga? Singgih, Rama. Rombongan saya dihadang orang-orang bercadar dihutan Telepak. Bhre Kertabhumi mengerutkan dahi. Rombongan pasukan Bhayangkara yang menyamar sebagai rombongan pedagang dan sedianya hendak mengantarkan Raden Jaka Sujanma ke Blambangan dihadang orang-orang tak dikenal, itu berarti para penghadang tahu rencana kepergian diam-diam Raden Jaka Sujanma ke Blambangan (Shashangka, 2016:233-234)'”.
Peristiwa terus berlanjut ketika banyak ditemukan para pejabat dilingkungan istana yang melakukan penghianatan, dibuktikan dengan selalu bocornya setiap gerak-gerik Kertabhumi dan keturanannya dimanapun mereka berada. Sehingga Bhre Kertabhumi harus memutar otak dan mengambil tindakan cepat untuk menyelamatkan keluarganya dari serangan orang-orang yang patut dicurigai sebagai pelaku dan otak penghianatan.

"Penghadangan rombongan
Raden Jaka Sujanma
membuktikan bahwa rencana
Bathara Ring Majapahit sudah
bocor. Dan jelas, para
penghadang berasal dari pihak
yang tidak senang dengan
Bathara Ring Majapahit.
Penghadangan terjadi di wilayah
Paguhan. Maka pihak Kedhaton
Paguhan patut dicurigai. Namun
ada warta yang didapat Arya
Bangah di Dukuh Ganten yang
berada dilereng utara Gunung
Brahma yang merasa terganggu
dengan banyaknya pasukan yang
datang dari arah selatan. Hanya
dua tempat yang dicurigai
sebagai asal pasukan tak
dikenal: Kabalan dan Tumapel
(Shashangka, 2016: 235-236)".

Jika analisa Bhre Kertabhumi tidak meleset, maka dapat dipastikan Kabalan dan Tumapel sebagai tempat yang patut dicurigai, dengan alasan Kabalan berpusat disebelah barat daya Gunung Brahma dan Gunung Mahameru. Sementara Tumapel berpusat di sebelah barat dari kedua gunung tersebut. Namun juga tidak menutup kemungkinan pasukan yang tidak dikenal berasal dari dari Wirabumi yang berpusat di tenggara Gunung Mahameru. Dimana pada saat ini tahta Kabalan diduduki oleh Dewi 


\section{Jurnal Ilmu Sastra}

Mahamahisa Dyah Sawitri dan dia juga memegang sementara tampuk kekuasaan Paguhan pasca meninggalnya Bhre Paguhan Katelu yang tewas terbunuh di Canggu dan dia adalah istri Raden Girisawarhana Dyah Suryawikrama yang menduduki tahta Wengker yang bergelar Bhre Wengker Katelu.

Sedangkan tahta Tumapel sementara masih dipegang oleh Raden Kertarajasa yang kini menduduki tahta Majapahit dan Wirabumi mengalami kekosongan penguasa pasca Raden Gajah atau Bhre Napati atau yang dikenal dengan Minak Jingga terbunuh oleh Raden Aji Ratna Pangkaja atau Raden Damar Wulan pada Saka Warsa 1355 atau 1433 Masehi. Namun demikian tidak cukup alasan jika Tumapel dijadikan pelaku atau dalang dalam peristiwa tersebut, yang patut dicurigai adalah Kabalan yang tidak lain adalah Wengker dibawah naungan Girisawardhana.

Kemudian permasalahan semakin memuncak dengan ditemukannya bubuk mesiu di Dermaga Sumengka tepatnya ditengah aliran Canggu yang dibawa oleh para prajurit laut Majapahit, yang menjadi suatu isyarat dan tanda bahwa mereka telah siap untuk menciptakan huru-hara dilingkungan Kedhaton Majapahit.

"Kalian sedang apa? Mengapa kalian diam? Dalam ketegangan mendadak terdengar ledakan dari aliran Canggu, Semua yang lalu lalang terkejut. Bahkan para wanita penjual makanan sudah mulai berdatangan, menjerit ketakutan. Jung prajurit Bhayangkara terbakar? Sebuah tembakan cetbang mengenai jung. Beberapa prajurit Bhayangkara melompat ke sungai dan beberapa kejap berikutnya dengan penuh amarah mereka berlari mengejar gerobak yang didalamnya terdapat keranjang yang berisi bubuk mesiu, delapan prajurit laut Majapahit yang ketahuan mencoba melarikan diri dan melakukan perlawanan (Shashangka, 2016:248-249)'”.

Temuan di atas semakin mengukuhkan bahwa upaya kudeta sudah didapan mata, namun berhasil digagalkan oleh Bhayangkara Majapahit. Hal ini mengindikasikan bahwa yang namanya penghianatan pasti datang dari orang terdekat atau orang yang dipercayai. prajurit laut Majapahit telah membuktikan bahwa melalui tindakan gerilya mereka mencoba memecah belah dan menghancurkan kedamaian yang ada dilingkungan Majapahit.

Berdasarkan uraian tersebut di atas, maka tidak mengherankan politik kekuasaan bisa mendatangkan malapetaka kepada berbagai pihak. Dalam hal ini, pihak-pihak yang merasa terganggu akan keberhasilan kerajaan lain, akan berupaya melakukan serangkaian tindakan dan teror untuk mengalihkan perhatian dan kepercayaan masyarakat terhadap kerajaan tersebut. Dalam Politik kekuasaan, tindakan makar / kudeta menjadi hal yang biasa jika seseorang betul-betul menginginkan kekuasaan. Maka tidak mengeherankan, jika banyak kerajaan besar hancur karena ulah dari kerabat dan orang-orang kepercayaan sendiri apakah itu berasal dari keluarga, anak, istri, kerabat dan sahabat melalui politik adu domba.

\section{SIMPULAN}

Konsep politik kekuasaan sebenarnya menghadirkan tantangan tersendiri bagi seorang penguasa dan orang yang dikuasai. politik hadir untuk memberikan pandangan dan sikap kritis terhadap kebijakankebijakan yang yang diambil penguasa apakah telah sesuai dengan nawacitanya 


\section{Jurnal Ilmu Sastra}

yang selalu digadang-gadangkan atau tidak.

Namun demikian tetap saja kekuasaan menjadi ikon penentu dari kebijakan politik yang diambil.

Faktanya, seringkali praktik penundukan / eksekusi yang dilakukan sang penguasa pada kala itu dilakukan dengan cara-cara yang tak lazim dan berseberangan dengan nilai-nilai kemanusiaan seperti memanipulasi sebagian orang yang dimanifestasikan dalam bentuk keinginankeinginan, ideologi, dan hasrat.

Namun demikian, praktek penundukkan inilah yang tidak dapat dilakukan oleh Girisawardhana, dimana dalam proses eksekusi penundukan Kerajaan Keling ia belum mampu mengalahkan Bhre Kertabhumi terutama dalam hal ketenangan, strategi dan kepintaran dalam hal menguasai medan atau area dimanapun ia berada. Sejarah juga telah membuktikan bahwa seseorang tidak memiliki kemampuan akan berupaya menggunakan segala macam cara untuk memperoleh kekuasaan dan mengenyampingkan yang namanya akal sehat dan hati nurani.

Hadirnya politik kekuasaan, pada dasarnya hadir untuk memberikan pandangan dan pengetahuan bahwa tidak ada yang namanya politik tanpa adanya kekuasaan dan begitu juga sebaliknya. Hanya saja, dalam berpolitik sebaiknya mengutamakan kepentingan hajat hidup orang banyak bukan mengutamakan kepentingan pribadi, kelompok ataupun golongan. Seperti halnya yang dilakukan oleh Girisawadhana dalam Novel Sabdo Palon Pudarnya Surya Majapahit yang mencoba menghalalkan segala cara untuk memperoleh kekuasaan.

\section{DAFTAR PUSTAKA}

A. Hoogerwerf. 1985. Politikologi. Jakarta: Erlangga.
Andrew Heywood. 2007. Political Theory: An Introduction, Second Edition, Palgrave New York. Yogyakarta: Pustaka Pelajar.

Almond, A. Gabriel. 2008. Dasar-Dasar Ilmu Politik. Jakarta: PT. Gramedia Pustaka Utama.

Budiardjo, Miriam. 2003. Dasar-dasar Ilmu Politik, Edisi Revisi, Jakarta: Gramedia.

Endraswara, Suwardi. 2011. Metodologi Penelitian Sastra. Cetakan Ke-1. Jakarta: Caps.

George Ritzer \& Douglad J. Goodman. 2007. Teori Sosiologi Modern. Jakarta: Kencana.

Hotman, Siahaan. 1986. Pengantar Kearah Sejarah dan Teori Sosiologi. Jakarta: Erlangga.

Imam Hidayat. 2009. Teori-Teori Politik. Malang: SETARA press.

Rafael Raga Maran. 2001. Pengantar Sosiologi Politik. Jakarta: Rieneka Cipta.

Shashangka Damar. 2016. Novel Sabdo Palon "Pudarnya Surya Majapahit". Banten: PT. Kaurama Buana Antara.

Soekanto, Soerjono. 1994. Kamus Sosiologi. Jakarta: PT. Raja Grafindo Persada. 